\title{
Research on Teacher Professional Development for College English
}

\author{
Yan Liu
}

Teaching and Research Institute of Foreign Languages, Bohai University, Jinzhou, 121013, China

2439989361@qq.com

Keywords: college English; teacher professional development; connotation; theory; pathway

\begin{abstract}
Teacher professional development is the need of education reform and era development. This study can enrich the Chinese teacher's professional development theory, in order to improve college English teachers' professional level and quality of college English teaching. It analyzes the connotation of teacher professional development, researches the teacher professional development stage theory, lifelong education theory and the theory of career development theory of teacher professional development, points out some approaches to college English teachers' professional development, specific include: the construction of college English teachers' professional development of lifelong education system, and promote the college English teachers' professional development by reflective teaching, guide the development of college English teachers' occupational career planning, building, teaching and research of the combination of integrated model of professional development and utilization of education informatization autonomous learning platform to speed up teacher professional development, etc.
\end{abstract}

\section{Introduction}

Teacher professional development refers to the teacher as a professional, constantly improve the process on the professional thought, professional knowledge, professional ability, etc. namely it's a process that a novice professional development into the process of expert teachers. Education should be a personal whole life process of continuous learning, lifelong learning will become an unstoppable trend. To train talents for the society and the national teacher, more should with lifelong education as the goal, to the lifelong learning throughout his life, constantly improve the professional knowledge and professional ability, constantly absorbing the field and related fields of knowledge and the latest research results, improve the teaching and scientific research ability, keep up with The Times development, and in the process of education teaching, teach students learning and cognition.

English as an international language all over the world people's attention and concern, is also used as an official language in many countries. College English teaching is an organic part of higher education, college English course is the compulsory foundation course of college students. College English is a foreign language teaching theory as the guide to English language knowledge and application skills, cross-cultural communication and learning strategy as the main content, and collect a variety of teaching mode and teaching means for the integration of teaching system. The teaching aim of college English is to cultivate the students' English comprehensive application ability, especially listening and speaking skills, to make them in the future study, work and social activities can communicate effectively in English, at the same time to improve their ability of autonomous learning, improve the comprehensive cultural quality, to meet the need of social development in our country and international communication.

Teachers' professional development is vital for the foreign language education reform, the process and effect of directly affect the students learning a foreign language. The current college English teachers' professional quality is still a weak link in higher education, has not been a fundamental change, and the requirement of quality education and a certain distance, is difficult to keep up with the pace of the development of social economy and education in the 21st century. Placed in the social environment of English teachers' professional development is a continuous process of life, lifelong learning is the key to teachers remain its scientific and advanced and source, is the teacher get the eternal power of latest knowledge, ability and quality, and college English 
teachers in the new times and the only way for the development of students. Through this topic research, formulate the specific pathway to college English teachers' professional development level, can enrich theory of teacher professional development in our country, in order to improve to college English teachers' professional level and quality of college English teaching.

\section{Connotation on Teacher Professional Development}

Connotation refers to the inner self-restraint or quality. Connotation is an abstract sense, is a person of one person or one thing a cognitive sense, meaning not generalized, is confined to a certain person treat a person or one's point of view. Connotation is not on the surface of things, but the inner, hidden in the depths of things, need to explore and dig to see. Teachers' professional development for teachers' professional growth as the goal, to improve the teachers' beliefs, and other professional knowledge, skills and emotional quality of content, is a dynamic sustainable development of the process. In this process, the teacher not only need to keep learning and to explore the process to develop professional connotation, improve their professional level, expansion of professional knowledge, also need the teacher's subjectivity into full play, to achieve maximum life value. Details of teachers' professional development connotation as shown in Fig. 1.

\begin{tabular}{|c|c|}
\hline \multicolumn{2}{c|}{ Teacher professional development } \\
\hline Abide by the professional ethics & Establish professional personality \\
\hline Expand professional knowledge & Formed professional thoughts \\
\hline Enhance professional ability & Developing professional self \\
\hline
\end{tabular}

Fig. 1. Connotation on teacher professional development

For all contents as shown in Fig. 1 in the brief description is as follows:

(1) Abide by the professional ethics. The teachers professional ethics is in engaged in education work necessary to follow the code of conduct and moral quality, is an organic part of social ethics, is the moral requirement of teachers' profession special, is the specific embodiment of general social morality in the teachers' professional.

(2) Expand the professional knowledge. Professional knowledge is an important professional quality of teachers, is the base of the work in the education teaching ability, education is growing soil of wisdom and art education, the source of the teachers' influence to form. For teachers of teaching professional knowledge including discipline knowledge, knowledge and education context knowledge, etc. [1].

(3) Enhance professional ability. The teachers' professional ability is in teachers' education teaching ability, on the basis of accumulating experience through the education practice, constantly improve themselves, continuously innovation and development of a qualified teacher should have the full ability ". Promote professional ability is the necessary way to realize the goal of education and promote teachers' professional development.

(4) Establish professional move. Teachers' professional personality is the inner motive power of teachers' professional development, is the touchstone of divine dedication, sense of responsibility and professional teachers. Teachers' professional personality mainly includes tolerance, appreciate the spirit and passionate to life [2]. Its explicit form is "love" in the process of education and teaching of sow.

(5) Formed professional thoughts. How to cultivate the teachers' professional thought is the important problem of teachers' professional development is a stable teacher troop, remove education crisis, the development of the cause of education. Including the teachers' professional thought, life-long service to the cause of education, keep improving, use the method of education teaching task, and promote the healthy development of the education career history, sense of responsibility.

(6) Developing professional self [3]. The teacher professional self is created in your career and in accordance with their own interests, ability and personality alone lifestyle education teaching and 
the individual in the professional knowledge, ideas, formed in the life of the sum of the value system and teaching style.

\section{Theory on Teacher Professional Development}

Theory, refers to study the general pattern, structure and principles of the system of knowledge, is the natural and social phenomena, in accordance with the known knowledge or cognition, through the methods of generalization and deductive reasoning, logical inferential summarized. Through the basic theory, provide a basis for the study of the subject. Teacher professional development mainly includes the following theory:

(1) Teacher professional development stage theory. Teacher professional development stage theory is based on the above research and achievements of the theory of career development, is an American scholar, founder of the Fuller, become teachers the beginning of the development of theoretical research. The theory and the path points the teacher professional development stage, help teachers define their steps to experience in the process of professional development, help the teacher according to the development stage to set up the development of short-term and long-term goals, as well as to the school or teacher training institutions in light of the characteristics of teacher professional development to provide support to promote the development of professional terms. According to different content, the teachers that from students to professional teachers growth process is divided into the following four stages: preteaching concerns stage, early concerns abort survival stage, would situations concerns stage and concerns abort students stage.

(2) Lifelong education theory [4]. Lifelong education by the United Nations educational, scientific and cultural organization as early as adult education experts R.L Mr Ongrand officially put forward in 1965. "Education R.L ongrand thought education can't stop in childhood and adolescence, as long as people alive, it should be continued, to adapt to the requirement of the continuity of individual and society". From the longitudinal structure point of view, education is not restricted to adolescent stage and should throughout one's life; Look from the horizontal structure, the lifelong education is not limited to school education, also includes any form of education beyond the school; From a deeper perspective, lifelong education to human education and closely linked to the social production and life, learning and work and life while learning is the organic unity of the people in the modern society activity.

(3) Career development theory [5]. Career refers to a person based on the ideal of a series of work choices, which is formed by the long-term goals and related education or training activities, is a planned career development. Career development theory has experienced five stages, the first stage, the career guidance theory is put forward and the basic model; The second phase, consultants centered "to guide school" dominant period; The third stage, pay attention to personal development period; The fourth stage, the time of formation of the vocational guidance under the theory of career development; The fifth stage, vocational guidance under the theory of career development of mature, perfect and internationalization. Through career planning can grasp their own destiny, which is beneficial to self-awakening and self-positioning, achieve the ideal channel can be found, and realize the harmony of man and career development.

\section{Pathway on Teacher Professional Development for College English}

Based on college English teaching to teacher's new request and the problems existing in the college English teachers' professional development, teachers' professional development related theory, combined with national policies and regulations and related document spirit by the competent department of education, with reference to the latest research results at home and abroad [6-10], and use for reference the experience of typical developed countries, put forward the college English teachers' professional development pathway is as follows:

(1) Construct a lifelong education system for college English teachers' professional development. Beyond the stage, institutionalized and lifelong education system throughout the life, always is a kind of new education model, has the individuality, by default, the value of the education target in 
the implementation of the education form has diversity, has integrated in the spatial and temporal variations of education category, open on the education resource support. Specific methods include: teachers need to set up the lifelong education idea; Teacher should become a model for life-long learning; To realize the integration of teachers' pre-service education and in-service education. Construction of teachers' continuing education and on-the-job training of legal protection; The establishment of a democratic harmony and open relationship between teachers and students, the formation of learning community; Strengthening teachers' lifelong education system of supervision mechanism; With information technology basic quality, form lifelong learning ability; Strengthen the teachers' lifelong education system to construct research.

(2) Promote college English teachers' professional development by reflective teaching. Reflective teaching is the teaching main body by the action research, constantly explore and resolve themselves and the problem of teaching purpose and teaching tools and so on, to "learn to teaching" and "learning to learn", efforts to improve teaching practice rationality, make oneself become a scholarly teachers, the process of reflective teaching process is also a teacher reflection. Reflective teaching is in order to explore and solve the problem of teaching as the basis, with strong creativity. Applying reflective teaching college English teaching, and encourage teachers to focus on their own teaching practice, in itself before teaching, teaching reflection and teaching at the same time, the defects and advantages of after improve teachers' professional ability, thus to improve the teaching quality on the whole. This kind of teaching theory based on personal practice, can effectively promote the professional development of teachers and improve the teaching quality.

(3) Guide college English teachers to plan their career development. Career planning refers to the individual and organization, the combination of the subjective and objective conditions for determination of his career to the person, on the basis of analyzing and summarizing, interests, hobbies, ability and characteristics of the way of analysis and weigh, combining with the characteristics of era and according to the professional tendency, determine the best career goals, and make effective arrangements to achieve this goal and plan. Teachers' career is a teacher in the whole life the most important stage, is the process of teachers "education", help teachers to establish development goals, can also help teachers to meet the needs of future competition and society. According to the characteristics of college English teachers to provide a variety of channels, including education and training, to encourage and guide to career planning, college English teachers to find and explore a new mode for their professional development.

(4) Construct professional development model of the integrated teaching and research. Teaching and research are two core tasks of teachers in colleges and universities, both full accord, is an organic unity. Scientific research is to improve the teachers' teaching level and ensure teaching quality; Teaching is to realize the transformation of scientific research achievements, important way to improve the efficiency of the scientific research work. The integration of teaching and research is to improve the level and quality of talent cultivation of higher effective way. The integration of teaching and research is to realize the overall goal and the organic combination of teachers' personal goals. Specific strategies include: correct understanding of the relationship between the teaching and scientific research; Through the interaction of teaching and research integration professional development foundation; Structures, teaching and scientific research platform to promote the integration of development; Innovation evaluation mechanism to mobilize the enthusiasm of teachers' professional development; Ensure to provide various support the integration of teaching and research and development.

(5) Use education informatization autonomous learning platform to speed up teacher professional development. Education informatization is the basis of the modernization of education and conditions, is the inevitable product of the development of the era of information technology education, set up the modern concept of education is the key to realize the modernization of education. Teachers must set up the concept of professional development, the use of independent learning platform to provide education informatization of education information and teaching resources, to promote their professional development. Autonomous learning platform including repository construction system, teacher preparation system and autonomous learning system, etc., 
according to the learning content, learning situation, learning conditions, characteristics and factors of individual learning consciously and actively choose learning methods, organization learning activities, the final show is willing to learn, good at learning, longer than creating, meet the needs of the teachers' professional development.

\section{Conclusion}

Under the background of national work of education attaches great importance to research on this topic, not only conforms to the theme of the college English teaching reform, but also embodies the care for college English teachers. Research results to guide college English teachers' effective reflection and practice, improve the quality of college English teachers, to better promote the development of foreign language education career and so on, has the very vital significance [11]. About theory, enrich the theory of teacher's professional development, broadening the research field of foreign language teaching. Practices, to provide ideas to the British educational reform in common colleges and universities, to provide guidance for college English teachers' growth and development, provide the basis for teacher development training, education management department.

\section{References}

[1] Y. P. Wu, "On the independent development of young teachers' professional knowledge," Modern Education Science, vol. 4, no. 1, pp. 8-9, 2010.

[2] Good teacher blog, "The professional personality of excellent teachers," http://blog.sina.com.cn/s/blog_6de3bbe80101lhzk.html, 2016-4-5.

[3] Online document sharing platform, "The connotation and ways of teachers' professional development," http://www.doc88.com/p-096107916177.html, 2016-4-5.

[4] H. Y. Gao, J. Zhang, "The historical evolution of the theory of lifelong education," Journal of Jilin TV \& Radio University, vol. 28, no. 2, pp. 36-37, 2015.

[5] X. Yu, "Career development theory and the construction of teachers' team in the course of career development education," China Economist, vol. 29, no. 12, pp. 205-206, 2014.

[6] X. X. Wu, "On Construction of Teachers Life-long Education System under the Concept of Lifelong Education," Continue Education Research, vol. 27, no. 3, pp. 45-46, 2010.

[7] Y. J. Xie, H. H. Hu, "On Reflective Teaching and Professional Development of College English Teachers," Journal of Hunan University of Commerce, vol. 23, no. 1, pp. 126-128, 2016.

[8] Z. Z. Ding, "Career development planning and career expectation of young teachers in the system of Open University in Jiangsu," Educational information, vol. 58, no. 25, pp. 86-87, 2015.

[9] H. Y. Wei, N. Sang, J. F. Xie, et al, "Discussion on the construction mode of integrated team of teaching and scientific research in Colleges and Universities," China Education Innovation Herald, vol. 43, no. 2, pp. 43, 2014.

[10] R. F. Qu, "Using information platform to promote teachers' professional development," Liaoning Education, vol. 43, no. 14, pp. 49-50, 2014.

[11] Y. P. Rui, "An empirical study on the professional development of College English teachers: Teaching reflection and teaching practice as an example," Doctor's degree of Shanghai International Studies University, 2011. 